\title{
BesEARCA INS S \\ PHYSICAL ACI \\ Baseline natural killer cell cytotoxicity is enhanced in the presence of post-exercise autologous serum
}

Autor(es): $\quad$ Gupta, Priti; Bigley, Austin; LaVoy, Emily C.

Publicado por: Imprensa da Universidade de Coimbra

URL persistente:

URI:http://hdl.handle.net/10316.2/44152

DOI:

DOI:https://doi.org/10.14195/2182-7087_ex2018_89

Accessed : $\quad$ 26-Apr-2023 12:44:18

A navegação consulta e descarregamento dos títulos inseridos nas Bibliotecas Digitais UC Digitalis, UC Pombalina e UC Impactum, pressupõem a aceitação plena e sem reservas dos Termos e Condições de Uso destas Bibliotecas Digitais, disponíveis em https://digitalis.uc.pt/pt-pt/termos.

Conforme exposto nos referidos Termos e Condições de Uso, o descarregamento de títulos de acesso restrito requer uma licença válida de autorização devendo o utilizador aceder ao(s) documento(s) a partir de um endereço de IP da instituição detentora da supramencionada licença.

Ao utilizador é apenas permitido o descarregamento para uso pessoal, pelo que o emprego do(s) título(s) descarregado(s) para outro fim, designadamente comercial, carece de autorização do respetivo autor ou editor da obra.

Na medida em que todas as obras da UC Digitalis se encontram protegidas pelo Código do Direito de Autor e Direitos Conexos e demais legislação aplicável, toda a cópia, parcial ou total, deste documento, nos casos em que é legalmente admitida, deverá conter ou fazer-se acompanhar por este aviso. 


\section{ANNALS OF RESEARCH IN SPORT AND PHYSICAL ACTIVITY}




\title{
BASELINE NATURAL KILLER CELL CYTOTOXICITY IS ENHANCED IN THE PRESENCE OF POST-EXERCISE AUTOLOGOUS SERUM
}

\author{
Priti Gupta1; Austin Bigley ${ }^{1}$; Emily C. LaVoy ${ }^{1}$
}

KEYWORDS: -NKCA, cycling, stress hormones

Natural Killer (NK) cells recognize and eradicate tumor cells. Multiple studies have shown that the killing capacity of each NK-cell (termed Natural Killer Cell Activity(NKCA)) is greatest during recovery from exercise. However, the factors responsible for increased NKCA per cell after exercise are not fully understood. It is thought that exercise-induced phenotypic shifts in NK-cell subsets play a role. Exercise also alters the concentration of various stress hormones(glucocorticoids) and cytokines, which could also impact NKCA. PURPOSE: To determine the role of exercise-induced shifts in NK-cell subsets, cytokines and hormones on exercise-induced changes in NKCA per cell. METHODS: Healthy adults ( $n=13,7$ women; $31.9 \pm 7 y r s$ ) cycled $30 \mathrm{~min}$ at $115 \%$ of their lactate threshold power. Blood was collected pre, post-, and $1 \mathrm{H}$ post-exercise. Effector cells isolated from blood were incubated with K562 or U266 tumor target cells in the presence of autologous serum. NKCA was assessed after $4 \mathrm{~h}$ by measuring lysed target cells in a flow cytometry based assay. NK cell phenotype was also assessed by 10-parameter flow cytometry. To investigate the effects of hormones and cytokines released during exercise, pre-exercise effector cells were incubated with target cells in the presence of pre-, post-, and $1 \mathrm{H}$ post-exercise serum. The effect of shifts in NK-cell subsets was determined by incubating pre-, post- and $1 \mathrm{H}$ post-effector cells with target cells in the presence of pre-exercise serum. Linear Mixed Models were used to assess the effect of time and condition on NKCA on a per cell basis and NK-cell phenotype. RESULTS: The cytotoxicity of pre-exercise effector cells was significantly increased against the HLA-expressing target cells(U266) when incubated in $1 \mathrm{H}$ post-exercise serum (Pre vs. post vs. $1 \mathrm{H}$ post $=0.318 \pm 0.039 v$ s. $0.334 \pm 0.039 v s$. $0.438 \pm 0.039, p<0.05)$. Incubation

\footnotetext{
1 University of Houston, Houston, Texas, USA

* Corresponding Author-Tel:+1(281)8910482 E-mail address: pgupta14@uh.edu. Universiry of Houston.

Email: tanug3110@gmail.com; pgupta14@uh.edu
} 
of pre-effector cells with1H post-exercise serum significantly reduced the proportion of cells with the inhibitory phenotype NKG2A+/ NKG2C-(Pre vs.post vs. $1 \mathrm{H}$ post $=45.0 \pm 6 \%$ vs. $44.2 \pm 6 \%$ vs. $42.8 \pm 6 \%, p<0.05)$ on NK cells. There was no difference in cytotoxicity of pre, post-, $1 \mathrm{H}$ post-effector cells incubated with pre-exercise serum (Pre vs.post vs.1H post $=0.321 \pm 0.047 v s$. $0.282 \pm 0.047 v s$. $0.323 \pm 0.047, p<0.05)$. CONCLUSION: The cytotoxicity of resting NK-cells is enhanced following incubation with autologous serum drawn $1 \mathrm{H}$-post exercise. This corresponds with decreased proportion of NK-cells exhibiting the inhibitory phenotype NKG2A+/NKG2C-. We suggest that exercise-induced changes in serum increase NKCA. Future work will identify the levels of hormone and cytokines that are present in $1 \mathrm{H}$ post-exercise serum. 